\title{
Influence of Midazolam and L-Arginine on Clinical Observations and Biochemical Changes in Rat Liver Induced by Pentylenetetrazole
}

\author{
Ankica Jelenkovic ${ }^{1}$, D. Marina Jovanovic ${ }^{2}$, Dragan Đurđević ${ }^{2}$, Danica Stanimirovic ${ }^{3}$, \\ Dubravko Bokonjić 2 , IvanaVasiljevic ${ }^{2}$, Rosa Mihajlovic ${ }^{4}$ \\ 'Institute for Biological Research "Sinisa Stankovic", University of Belgrade, Serbia \\ ${ }^{2}$ Military Medical Academy, Institute for Medical Research, Belgrade, Serbia \\ ${ }^{3}$ Institute for Biological Sciences, National Research Council, Ottawa, Canada \\ ${ }^{4}$ Institute for Rehabilitation, Belgrade, Serbia \\ Received December 18, 2008 \\ Accepted March 9, 2009
}

\begin{abstract}
Certain types of convulsions may lead to multiorgan dysfunction. We investigated whether the chemoconvulsant pentylenetetrazole (PTZ) could influence energy synthesis in the liver besides evoking convulsions in adult male Wistar rats. In $80 \%$ of the rats PTZ $(100 \mathrm{mg} / \mathrm{kg}$ body weight, administered intraperitoneally - i.p.) evoked generalised clonic convulsions (GCCs) and in 60\% of the rats generalised clonic-tonic convulsions (GCTCs) within 4 min after its administration. Cytochrome $c$ oxidase activity was simultaneously reduced approximately three-fold compared to $0.9 \% \mathrm{NaCl}$-treated (control) rats $(p<0.01)$. Midazolam administered before PTZ was an excellent anti-convulsant especially against GCCs $(p<0.05)$. However, it did not protect against the decrease in cytochrome $c$ oxidase activity induced by PTZ. In contrast to midazolam, pretreatment with L-arginine did not prevent PTZ-evoked convulsions. However, it offered some protection against the PTZ-mediated reduction in cytochrome $c$ oxidase activity. Our results open new avenues of research that will focus on the mechanisms of action of PTZ, midazolam and L-arginine with particular reference to their direct and/or indirect effects on liver function.
\end{abstract}

Convulsions, cytochrome c oxidase, liver, midazolam, pentylenetetrazole

Despite years of studies the pathophysiological mechanisms underlying epilepsy are still not completely understood. In particular multiple questions remain to be answered, mainly relating to epileptic therapy which still faces a high failure rate. Several general anaesthetics and benzodiazepines that are regularly used in surgical practice are often administered for the treatment of epileptic seizures (Rossetti 2007; Holtkamp 2007; Riss et al. 2008). However, there are little published data concerning biochemical changes in organs apart from the brain, particularly during and after epileptic seizures (Akbas et al. 2005). In our current study emphasis was placed on determining changes in energy synthesis in the liver during convulsions and defining the effect of midazolam, a benzodiazepine commonly used in human and veterinary surgery, as well as the effect of L-arginine.

Mitochondria are organelles whose main role is energy production. Accordingly, they are key components for determining cell survival. In contrast to smooth external membrane the inner mitochondrial membrane is wrinkled and forming crypts (cristae). As the number of crypts is directly proportional to the cell's energy demands, cells within the regions of the brain and liver tissue have the highest number of crypts.

Important oxido-reductive processes occur in mitochondria which result in the synthesis of adenosine triphosphate (ATP). The latter is an energy-rich compound responsible for the vast majority of processes requiring a high energy transfer (Kakkar and Singh 2007).

Reducing equivalents, such as NADH, are formed in the cytoplasm during glycolysis and are transported into mitochondria in order to assist the process of oxidative phosphorylation. The transfer of electrons from NADH to coenzyme Q is performed by the first respiratory complex (complex I). Coenzyme Q is a mobile electron transporter. Cytochrome $c$ is

Address for correspondence:

Ankica Jelenkovic

Institute for Biological Research "Sinisa Stankovic"

Bulevar Despota Stefana, 142

11000 Belgrade, Serbia

Phone/Fax: +381 113420606

E-mail: jelaka@yahoo.com

http://www.vfu.cz/acta-vet/actavet.htm 
a critical component of complex IV in the respiratory chain (Fig. 1). The energy released during the consecutive oxido-reductive steps of mitochondrial respiration is used for ATP synthesis (Horton et al. 1996).

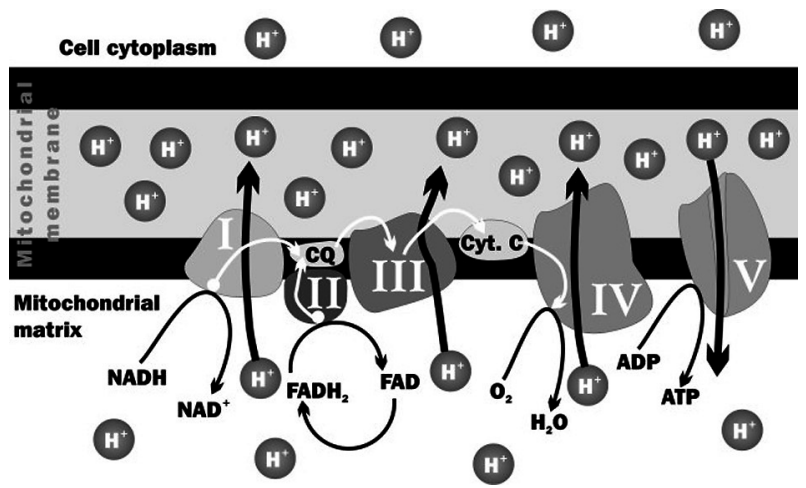

Fig. 1. A simplified scheme of respiratory complexes function (I-V)

For every four accepted electrons (by cytochrome $c$ oxidase) one molecule of oxygen is reduced to two molecules of water according to the following reaction: $\mathrm{O}_{2}+4 \mathrm{e}^{-}+4 \mathrm{H}^{+} \rightarrow 2 \mathrm{H}_{2} \mathrm{O}$.

The source of electrons in the above reaction is the ferrous $\left(\mathrm{Fe}^{2+}\right)$ form of cytochrome $c$. The oxido-reductive components of complex IV are cytochrome a, cytochrome a3 and two copper ions. Copper atoms and the cytochromes are one-electron oxido-reductive components. Cytochromes transfer electrons from reduced to oxidised compounds, by cycling electrons from ferrous $\left(\mathrm{Fe}^{2+}\right)$ to ferric $\left(\mathrm{Fe}^{3+}\right)$ forms of iron atoms in the cytochrome prosthetic groups (Richter and Ludwig 2003). All cytochromes, except cytochrome c, are integral proteins of the inner mitochondrial membrane.

Incompletely reduced oxygen species, particularly the notorious superoxide anion, are by-products of mitochondrial respiration (Camello-Almaraz et al. 2006). A great number of incompletely reduced oxygen species are very tightly bound to the cytochrome $c$ oxidase enzymatic complex. In contrast, their binding affinities to other electron transporters are not so high, thereby representing releasable sources of univalent reduced oxygen species. The main origin of such radical species is from complex I of the respiratory chain.

Because of their unique electrochemical characteristics (an uncoupled electron in their outermost orbit), incompletely reduced oxygen species rapidly react with other chemical compounds, thereby propagating both the abundance and reactivity of reactive oxygen radical species. These particularly reactive compounds can induce oxidative damage to all types of biomolecules, globally termed cellular oxidative stress (Jovanovic et al. 2006).

The activity of cytochrome $c$ oxidase, which indirectly indicates the degree of mitochondrial complex V activity, was examined in our current study. We tested whether pre-treatment with midazolam (a hypnotic benzodiazepine and pre-anaesthetic drug) and L-arginine [which can be oxidised to nitric oxide (NO)] could modify pentylenetetrazoleinduced convulsions (PTZ) as well as energy synthesis in rat liver.

\section{Materials and Methods}

Animals and treatments

Adult male Wistar rats were used for our experiments. They had free access to food and water and were kept under humane and environmentally controlled conditions (a temperature of $23 \pm 2{ }^{\circ} \mathrm{C}$ and a light: dark cycle of 13 $: 11 \mathrm{~h})$. One group of rats $(\mathrm{n}=10)$ received PTZ intraperitoneally (i.p.) $(100 \mathrm{mg} / \mathrm{kg}$ body weight). Another group $(\mathrm{n}=10)$ was treated with midazolam i.p. $(1.5 \mathrm{mg} / \mathrm{kg}$ body weight) $10 \mathrm{~min}$ before PTZ (as described above). The 
third group of rats $(\mathrm{n}=10)$ received L-arginine i.p. $(81 \mathrm{mg} / \mathrm{kg}$ body weight) $45 \mathrm{~min}$ before PTZ (as described above). The fourth group (control group) of rats $(\mathrm{n}=10)$ received only $0.9 \% \mathrm{w} / \mathrm{v} \mathrm{NaCl}$ i.p.

During a period of $4 \mathrm{~min}$ post-injection behavioural changes including generalised clonic and clonic-tonic convulsions were monitored in each rat. At the end of this period the rats were sacrificed by decapitation followed by isolation and immediate freezing of the livers (using liquid nitrogen). Until biochemical analyses were performed the livers were kept at $-70^{\circ} \mathrm{C}$.

The Ethics Board of the Department for Treatment of the Military Medical Academy, Belgrade, Serbia, approved the research presented in this manuscript.

Biochemical analyses

The activity of cytochrome $c$ oxidase (ferrous cytochrome C: oxygen oxidoreductase, EC 1.9.3.1.) was measured in a crude mitochondrial fraction by monitoring the decrease in absorbance during oxidation of ferrous cytochrome $c$ to its ferric form. Samples of liver were pre-treated with 7.5\% w/v deoxycholate (Kemika, Zagreb, Croatia). The reduction of cytochrome $c$ was mediated by $1 \mathrm{mM}$ sodium dithionite (Riedel-de Haen Ag. SeelzeHannover, Germany). Reaction kinetics was monitored during a period of 3-5 min at $550 \mathrm{~nm}$ in a potassium phosphate buffer $(0.05 \mathrm{M}, \mathrm{pH} 7.1)$. Reactions were started by adding a prepared sample $(0.05 \mathrm{ml})$ to a solution of $0.95 \mathrm{ml}$ reduced cytochrome $c$ (Merck, Darmstadt, Germany) (Hess and Pope 1960). The protein content within the prepared samples was determined by the method of Lowry et al. (1951).

Statistics

Incidence of seizures was tested by Fisher's exact probability test. Values of cytochrome $c$ oxidase are given as the mean $\pm \mathrm{SD}$ and were tested by Student's $t$-test. Significance was assumed if $p<0.05$.

\section{Results}

During a period of 4 min after PTZ administration $80 \%$ of the rats exhibited generalised clonic convulsions (Fig. 2). Generalised clonic-tonic convulsions were observed in 60\% of the rats.

Pre-treatment with midazolam resulted in a reduction in the incidence of both types of PTZ-induced convulsions (only $20 \%$ of rats exhibited convulsions of both types) $(p<0.05$ for generalised clonic convulsions).

In contrast to midazolam, pre-treament with L-arginine resulted only in a partial reduction in PTZ-induced convulsions ( $70 \%$ of rats exhibited generalised clonic convulsions and $50 \%$ of rats exhibited generalised clonic-tonic convulsions).

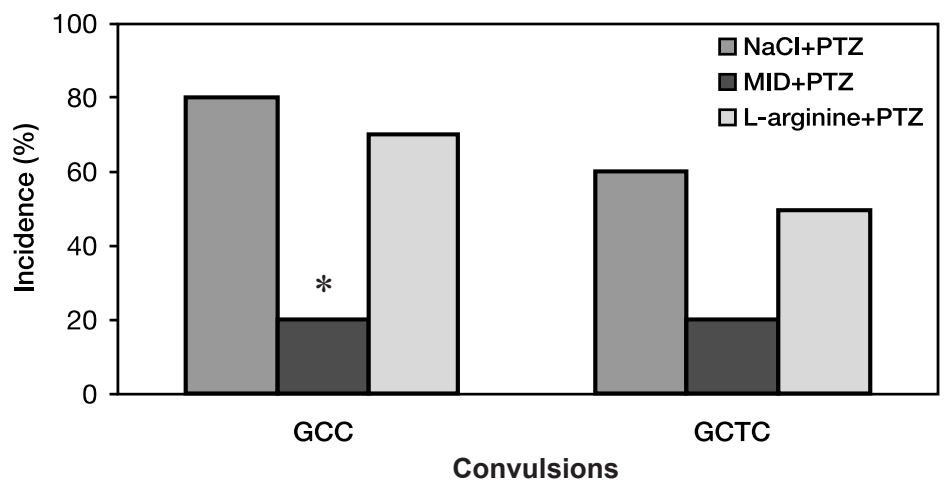

Fig. 2. The influence of midazolam and L-arginine on the incidence of PTZ-induced convulsions in Wistar rats ( $\mathrm{n}=10$ in each group).

* $-p<0.05$; significant difference from PTZ-treated rats (Fisher's exact probability test)

GCC: generalised clonic convulsions; GCTC: generalised clonic-tonic convulsions

The activity of cytochrome $c$ oxidase was found to be almost three times lower in PTZtreated rats $(p<0.01)$ compared to NaCl-treated rats (control group) (Fig. 3).

In comparison to the control group, the activity of cytochrome $c$ oxidase was also decreased in PTZ-treated rats which received midazolam 10 min before PTZ, i. e. such 
pre-treatment had no effect on the PTZ-induced decrease in cytochrome $c$ oxidase activity $(p<0.01)$ (Fig. 3).

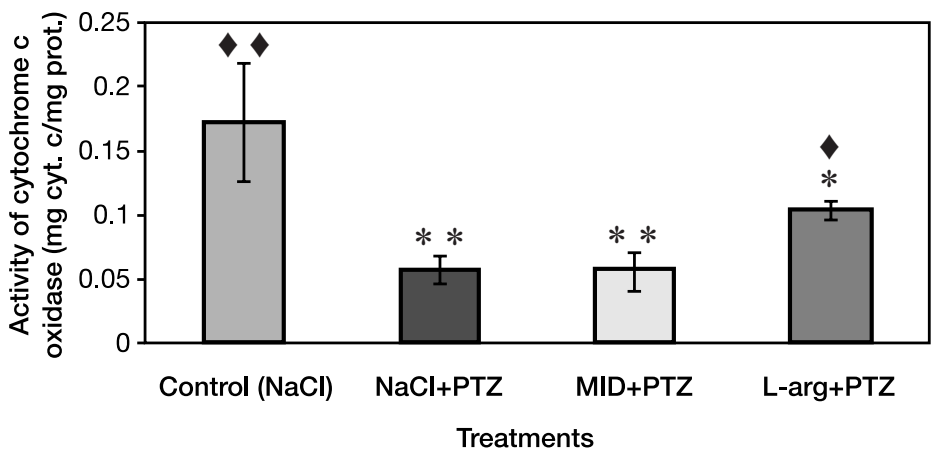

Fig. 3. The activity of cytochrome $c$ oxidase in the liver of PTZ-treated Wistar rats administered alone and after pre-treatment with midazolam (MID) and L-arginine (L-arg) $(\mathrm{n}=10$ rats in each group)

The data are expressed as mean $\pm \mathrm{SD}$. $*, * *$ - significant difference from control-treated rats, $\bullet-$ significant difference from PTZ-treated rats (Student's $t$-test, $p<0.05,0.01$ )

Pre-treament with L-arginine caused attenuation (approximately 50\%) of the PTZinduced decrease of cytochrome $c$ oxidase activity, but this activity was not reverted to the control values $(p<0.05)$ (Fig. 3). The obtained increase of cytochrome $c$ oxidase activity was significant in comparison to PTZ-treated rats $(p<0.05)$.

\section{Discussion}

Our results indicated that within 4 min after the treatments, behavioural changes as well as reductions in energy synthesis in the liver of adult male Wistar rats were evident (Figs 2 and 3 ).

Midazolam is a benzodiazepine possessing anxiolytic, anti-covulsant, hypnotic and muscle relaxant features. Besides its antiepileptic effects discussed above, midazolam allows relaxation of tracheal smooth muscle and relaxation of smooth muscle in blood vessels. Both effects are achieved by disabling calcium ion entry and prevention of the effects of noradrenaline on calcium ion movements (Kobayashi et al. 1998). For these reasons, midazolam is a commonly used agent during pre-medication in surgical practice. In addition, it is also used for the treatment of the epileptic status.

Midazolam reduces the incidence of convulsions due to its agonistic activity at the level of $\gamma$-aminobutyric acid (GABA) receptors. Activation of benzodiazepine receptors, which colocalise with GABA receptors, promotes inhibitory mechanisms in the brain. This protective effect is important from the point of view of the commencement and spread of excessive and synchronised neuronal discharge (Beleboni et al. 2004). Midazolam can also inhibit glutamate release (Sakai and Amaha 2000) which can contribute to its anticonvulsant properties.

In contrast, pre-treatment of the rats with L-arginine prior to PTZ administration was not able to profoundly prevent PTZ-induced convulsions in the majority of the rats. L-arginine is a semi-essential amino acid and is implicated in a number of metabolic processes. One of these is NO synthesis, catalysed by nitric oxide synthase (NOS) (Jobgen et al. 2006). Published results have suggested a role for NO in mechanisms underlying the pathogenesis of epileptic seizure. Similarly to PTZ, NO induces an increase in cyclic guanosine monophosphate (cGMP) by binding to and activating guanylate cyclase that demonstrates 
its dichotomy, pro-convulsant and anti-convulsant action, a feature that has been confirmed by many investigators.

The unsuccessful prevention of PTZ-induced convulsions by L-arginine is in agreement with our previously published results regarding the anti-convulsant effects of N-G-nitro-Larginine-methyl ester, a NOS antagonist, against some features of PTZ-evoked convulsions (Jelenkovic et al. 2002).

It is known that one of the functions of cytochrome $c$ oxidase is the maintenance of the membrane potential, a process that demands an enormous quantity of energy. This feature of complex IV is negatively regulated by mitochondrial NOS activity (Cooper 2002). The interaction between enzymes in mitochondria is very complex and not homogeneous. It depends on many factors including both oxygen and NO concentrations (Cooper and Giulivi 2007). However, the detailed molecular mechanism of cytochrome $c$ oxidase inhibition by NO has not yet been unequivocally established.

Depending on the micro environmental conditions, the activity of NO on mitochondrial NOS can display both regulatory and deleterious effects. Taking into consideration that NO synthesis is increased via NOS and molecular oxygen, it was expected that PTZ and L-arginine would demonstrate synergistic actions, particularly inhibitory effects, on enzymatic complexes within the respiratory chain including the activity of cytochrome $c$ oxidase. However, our results indicated the opposite effect (Fig. 3). This could have been partly due to the influence of L-arginine on the blood flow to the liver. In blood vessels NO (synthesised from L-arginine) regulates the activity of smooth muscles via the activation of soluble guanylate cyclase and in that way controls blood vessel diameter and blood flow. Previous experiments have shown that L-arginine increases blood flow into the liver (Li et al. 2003), thereby offering enhanced oxygen supply which could be one form of protection from the toxic effects of PTZ.

PTZ deploys its effects through the brain's glutamatergic and GABA receptors (Lukomskaya et al. 2004; Huang et al. 2001) evoking both patterns of convulsions in most of the rats, suggesting insufficient participation of cytochrome $c$ oxidase in the maintenance of membrane potential, resulting in a decreased threshold for neuronal depolarisation. This is in partial agreement with the results from Eloqayli and co-workers who demonstrated decreased mitochondrial metabolism and glycolysis in astrocytes acutely exposed to PTZ in vitro (Eloqayli et al. 2002) and also with the findings of Bruno et al. (2002) who demonstrated increased hydrolysis of nucleosides in blood serum from acute PTZ-treated rats.

The recent finding that some types of glutamatergic receptors exist in the liver (James et al. 2005) gives a possible basis for PTZ to initiate the same pathophysiological processes in the liver as in the brain, in other words decreased cytochrome $c$ oxidase activity directly in liver. Therefore the result of direct PTZ-mediated effects on the liver can not be ruled out.

Despite glutamatergic receptors in the liver, decreased cytochrome $c$ oxidase activity could be indirect, as a consequence of generalised seizures evoked by PTZ and via energy depletion not only in the brain but also in the peripheral organs including the liver. Such an explanation was given by Akbas et al. (2005) who found a decreased anti-oxidant capacity in combination with increased oxidative stress in the liver after PTZ-evoked convulsions, most likely due to the liver's involvement in generalised metabolic disturbances that follow PTZ-evoked seizures.

PTZ deploys its convulsive effects via contrasting brain neurotransmitter systems (by affecting both inhibitory and excitatory pathways). Through its direct action on chloride ion channels, PTZ blocks the interaction of GABA with its appropriate receptors, thereby diminishing the permeability of chloride ions. In contrast, PTZ increases the activity of excitatory (glutamatergic) systems by its rapid effects on excitatory neuronal membranes by changing ion transport, especially that of calcium ions and by potentiating discharge 
of the neurons with consequent convulsive responses. Such convulsive reactions can be inhibited by antagonists of some ionotropic glutamatergic receptors (Jelenkovic et al. 2003). Since hepatocytes, in contrast to neuronal and muscle cells, do not have excitable membranes the direct effects of PTZ in the liver should be discussed from an ion-channel viewpoint.

The basic cytotoxic mechanism of PTZ is due to intracellular calcium ion overload achieved through different pathways. Firstly, calcium ion channels open due to activation of glutamatergic receptors. In addition, glutamatergic receptors open membrane sodium channels causing sodium ion entry and membrane depolarisation. This depolarisation causes a second pathway for calcium ion entry via voltage-dependent calcium ion channels.

It has been documented that ionotropic glutamate receptors and voltage-dependent calcium ion channels contribute to PTZ-evoked epileptic activity in the CA1 region of rat hippocampal slices (Omrani et al. 2003). In addition, calcium ions can permeate into the cell via the membrane $\mathrm{Na}^{+} / \mathrm{Ca}^{2+}$ ion exchange pump. Under conditions of increased intracellular calcium ion concentration, for example due to the effects of PTZ, the abovementioned membrane-located mechanisms start to function in opposite directions, exchanging intracellular sodium ions for extracellular calcium ions. Under conditions of energy insufficiency induced by prolonged glutamate action, energy-dependent processes for calcium ion extrusion or directing it toward intracellular stores (endoplasmic reticulum and mitochondria) are possibly non-functional (Stanimirovic et al. 1994).

A particularly serious point for cell survival is the mitochondrial calcium ion overload. Mitochondria are available to accept a huge quantity of calcium ions, the mechanism by which they maintain cytoslic calcium ion homeostasis. Oxygen and oxidative phosphorylation are necessary for the process of calcium ion sequestration; the transport of calcium ions is possible due to proton translocation through the inner mitochondrial membrane that forms an electrical gradient, along which electrons flow (via the respiratory chain). After binding to glycoproteins localised on the outer mitochondrial membrane, calcium ions are transported into mitochondria by extrusion, a process involving the removal of protons out from the mitochondria. The energy produced is used for taking on calcium with the help of mitochondria. This energy is transformed into metabolic energy, in other words, some of the generated energy is used for calcium ion sequestration, since mitochondria accumulate calcium ions until the cytoplasmic calcium ion concentration achieves physiological values. The synthesis and degradation of ATP in mitochondria are the two basic pathways used to provide energy via respiration (Mršulja and Kostić 1994).

Diminished cytochrome $c$ oxidase activity in the liver was also found in rats pre-treated with midazolam before PTZ. The extent of decreased cytochrome $c$ oxidase enzyme activity was similar to that seen in rats treated solely with PTZ (Fig. 3). Despite the fact that fewer convulsive seizures were observed in rats pre-treated with midazolam before PTZ, decreased cytochrome $c$ oxidase activity indicates mitochondrial respiratory chain insufficiency in the liver.

The effects of midazolam on cytochrome $c$ oxidase activity can be independent of its anticonvulsive effects. It could be due to direct effects of midazolam on liver mitochondria, by acting on mitochondrial benzodiazepine receptors. According to the results of Colleoni et al. (1996), midazolam inhibits a number of liver enzymes involved in the mitochondrial respiratory chain, including those in complex I, II and III. Thus, recovery of impaired liver respiratory processes as a consequence of PTZ treatment cannot be expected even though midazolam demonstrated excellent anti-convulsive effects.

In conclusion, the given dose of PTZ evoked different patterns of convulsions in adult male Wistar rats and severely affected the energy synthesis in the liver. The anti-convulsive effects of midazolam against PTZ-evoked convulsions were not reflected at the level of cytochrome $c$ oxidase activity in the liver. This was in contrast to L-arginine, a precursor 
for NO synthesis, which did not prevent PTZ-evoked convulsions, but diminished the PTZ-evoked decrease in cytochrome $c$ oxidase activity in the liver. The complex interplay between NO, glutamate and GABA in the brain is reflected by energy synthesis in the liver. In addition, the latter could at least partly be the result of direct effects of the administered compounds.

\section{Vliv midazolamu a L-argininu na klinické změny a biochemické ukazatele $\mathrm{v}$ játrech potkana indukované pentylentetrazolem}

Některé druhy křečí mohou vést $\mathrm{k}$ poruchám funkce mnoha orgánů. V naší studii jsme pozorovali zda prokonvulzivum pentetrazol (PTZ) může kromě křečí mít i vliv na energetickou syntézu v játrech u samců potkana kmene Wistar. U 80\% potkanů intraperitoneální injekce PTZ v dávce $100 \mathrm{mg} / \mathrm{kg}$ vyvolala generalizované klonické záškuby (GCCs) a v 60\% potkanů generalizované tonicko-klonické konvulze (GCTCs) během čtyř minut po jeho aplikaci. Zároveň poklesla aktivita cytochrom-C-oxidázy přibližně třikrát $\mathrm{v}$ porovnání $\mathrm{s}$ kontrolní skupinou potkanů, jimž byl podáván $0.9 \%$ roztok $\mathrm{NaCl}(p<0.01)$. Midazolam podaný před aplikací PTZ vykazoval vynikající antikonvulzivní účinky zvláště k potlačení GCCs $(p<0.05)$. Nicméně tato látka nevykazovala účinek proti poklesu aktivity cytochrom-C-oxidázy indukované PTZ. Naopak aplikace L-argininu před intraperitoneální aplikací pentanyltetrazolu bránila snížení aktivity cytochrom-C-oxidázy vyvolané PTZ, avšak neprokázala tlumící vliv na křeče vyvolané PTZ. Naše výsledky otvírají nové cesty pro výzkum mechanismu účinku PTZ, midazolamu a L - argininu se zvláštním zřetelem $\mathrm{k}$ jejich přímým a/nebo nepřímým účinkům na funkci jater.

\section{Acknowledgement}

The authors are grateful for the support from the Ministry of Science of the Republic of Serbia, contract number 143057.

\section{References}

Akbas SH, Yegin A, Ozben T 2005: Effect of pentylenetetrazol-induced epileptic seizure on the antioxidant enzyme activities, glutathione and lipid peroxidation levels in rat erythrocytes and liver tissues. Clin Biochem 38 : 1009-1014

Beleboni RO, Carolino RO, Pizzo AB, Castellan-Baldan L, Coutinho-Netto J, dos Santos WF, Coimbra NC 2004: Pharmacological and biochemical aspects of GABAergic neurotransmission: pathological and neuropsychobiological relationships. Cell Mol Neurobiol 24: 707-728

Bruno AN, Oses JP, Bonan CD, Walz R, Battastini AM, Sarkis JJ 2002: Increase of nucleotidase activities in rat blood serum after a single convulsive injection of pentylenetetrazol. Neurosci Res 43: 283-288

Camello-Almaraz C, Gomez-Pinilla PJ, Pozo MJ, Camello PJ 2006: Mitochondrial reactive oxygen species and Ca2+ signaling. Amer J Physiol Cell Physiol 291: C1082-1088

Colleoni M, Costa B, Gori E, Santagostino A 1996: Biochemical characterization of the effects of the benzodiazepine, midazolam, on mitochondrial electron transfer. Pharmacol Toxicol 78: 69-76

Cooper CE 2002: Nitric oxide and cytochrome oxidase: substrate, inhibitor or effector? Trends Biochem Sci 27: 33-39

Cooper CE, Giulivi C 2007: Nitric oxide regulation of mitochondrial oxygen consumption II: molecular mechanism and tissue physiology. Am J Physiol Cell Physiol 292: C1993-2003

Eloqayli H, Qu H, Unsgard G, Sletvold O, Hadidi H, Sonnewald U 2002: Effects of pentylenetetrazole and glutamate on metabolism of [U-(13)C]glucose in cultured cerebellar granule neurons. Neurochem Int 40: 181-187

Hess HH, Pope A 1960: Intralaminar distribution of cytochrome $c$ oxidase activity in human isocortex. J Neurochem 5: 207-217

Holtkamp M 2007: The anaesthetic and intensive care of status epilepticus. Curr Opin Neurol 20: 188-193

Horton RH, Moran LA, Ochs RS, Rawn DJ, Scrimgeour GK 1996: Principles of biochemistry. Prentice-Hall, Inc. London, Sydney, Toronto, Mexico, New Delhi, Tokyo, Singapoore, Rio de Janeiro, pp. 411-435

Huang RQ, Bell-Horner CL, Dibas MI, Covey DF, Drewe JA, Dillon GH 2001: Pentylenetetrazole-induced inhibition of recombinant gamma-aminobutyric acid type A (GABA(A)) receptors: mechanism and site of action. J Pharmacol Exp Ther 298: 986-995 
James JK, Nakamura M, Nakazato A, Zhang KE, Cramer M, Brunner J, Cook J, Chen WG 2005: Metabolism and disposition of a potent group II metabotropic glutamate receptor agonist, in rats, dogs, and monkeys. Drug Metab Dispos 33: 1373-1381

Jelenkovic A, Jovanovic M, Ninkovic M, Maksimovic M, Bokonjic D, Boskovic B 2002: Nitric oxide (NO) and convulsions induced by pentylenetetrazol. Ann N Y Acad Sci 962: 296-305

Jelenković A, Jovanović M, Ninković M, Maksimović M, Bošković B 2003: Nitric oxide (NO) and an NMDA receptor antagonist in pentylenetetrazole-induced convulsions. Acta Vet Beograd 53: 103-112

Jobgen WS, Fried SK, Fu WJ, Meininger CJ, Wu G 2006: Regulatory role for the arginine-nitric oxide pathway in metabolism of energy substrates: J Nutr Biochem 17: 571-588

Jovanović DM, Jelenković A, Vasiljević I, Bokonjić D, Čolić M, Marinković S, Stanimirović DB 2006: Intracerebral aluminium intoxication: An involvement of oxidative damage. In: Neurobiological Studies - From Genes to Behaviour (Eds: Ruzdijic S, Rakic Lj). Research Signpost 37/661 (2), Fort P.O. Trivandrum-695 023, Kerala, India, pp. 259-271

Kobayashi Y, Muldoon SM, Kiyose M, Hagiwara T, Kumasaka S, Okabe E 1998: Inhibition by midazolam of the adrenergic function in the isolated canine mesenteric vein. Acta Anaesthesiol Scand 42: 1157-1163

Li X, Benjamin IS, Alexander B 2003: The role of nitric oxide in systemic and hepatic haemodynamics in the rat in vivo. Naunyn Schmiedebergs Arch Pharmacol 368: 142-149.

Kakkar P, Singh BK 2007: Mitochondria: a hub of redox activities and cellular distress control. Mol Cell Biochem 305: $235-253$

Lowry OH, Rosebrough NJ, Farr AL, Randall RJ 1951: Protein mesurement with the Folin phenol reagent. J Biol Chem 193: 952-958

Lukomskaya NY, Rukoyatkina NI, Gorbunova LV, Gmiro VE, Magazanik LG 2004: Studies of the roles of NMDA and AMPA glutamate receptors in the mechanism of corasole convulsions in mice. Neurosci Behav Physiol 34: 783-789

Mršulja BB, Kostić VS 1994: Neurochemistry in neurological diseases (in Serbian). BIGZ-Beograd, pp. 104142

Omrani A, Fathollahi Y, Almasi M, Semnanian S, Mohammad S, Firoozabadi P 2003: Contribution of ionotropic glutamate receptors and voltage-dependent calcium channels to the potentiation phenomenon induced by transient pentylenetetrazol in the CA1 region of rat hippocampal slices. Brain Res 959: 173-181

Richter OM, Ludwig B 2003: Cytochrome c oxidase--structure, function, and physiology of a redox-driven molecular machine. Rev Physiol Biochem Pharmacol 147: 47-74

Riss J, Cloyd J, Gates J, Collins S 2008: Benzodiazepines in epilepsy: pharmacology and pharmacokinetics. Acta Neurol Scand 118: 69-86

Rossetti AO 2007: Which anesthetic should be used in the treatment of refractory status epilepticus? Epilepsia 48 Suppl 8: 52-55

Sakai F, Amaha K 2000: Midazolam and ketamine inhibit glutamate release via a cloned human brain glutamate transporter. Can J Anaesth 47: 800-806

Stanimirovic DB, Markovic M, Micic DV, Spatz M, Mrsulja BB 1994: Liposome-entrapped superoxide dismutase reduces ischemia/reperfusion 'oxidative stress' in gerbil brain. Neurochem Res 19: 1473-1478 